\title{
Knowledge assessment of women living in the Wielkopolska region concerning risk factors for cervical cancer
}

\author{
Dorota Gawdzik ${ }^{1}$, Karolina Chmaj-Wierzchowska ${ }^{1}$, Mieczysława U. Jurczyk $^{1}$, Stanisław Sporny ${ }^{2}$, \\ Tomasz Opala $^{1}$
}

${ }^{1}$ Department of Maternal and Child Health, University of Medical Sciences, Poznan, Poland

${ }^{2}$ Department of Dental Pathology, Medical University of Lodz, Lodz, Poland

\begin{abstract}
Introduction: Cervical cancer (CC) is a malignant tumor which for many years has been a serious epidemiological problem in Poland. This issue is important because CC is the second most common type of malignant tumor, after breast cancer, and the second most common cause of death among women. The aim of this study was to assess the knowledge and awareness of women living in the Wielkopolska region (Gniezno district) of risk factors for cervical cancer.

Material and methods: The study used the diagnostic poll method, based on a previously developed survey questionnaire. The study was carried out between March and April 2013. The study group consisted of 100 women, involving schoolgirls from the secondary school in Gniezno (Group I), workers (doctors, nurses and midwives) of two outpatient clinics in the Gniezno district (Group II) and patients of the same clinics (Group III).

Results: According to the respondents, the main cause of CC is human papillomavirus (Group II - 36\%) and genetic predisposition (Group III -35\%). It is alarming that $26 \%$ of women did not know the risk factors for CC.

Conclusions: It is necessary to improve health education, especially concerning the main factors affecting the development of CC, in order to reduce the morbidity and mortality rates related to this cancer.

Key words: cervical cancer, knowledge, risk factors.
\end{abstract}

\section{Introduction}

Cervical cancer (CC) is a malignant tumor which for many years has been a serious epidemiological problem in Poland $[1,2]$. This issue is important because $\mathrm{CC}$ is the second most common type of malignant tumor, after breast cancer, and the second most common cause of death among women [3-5]. Currently, an essential component in the fight against CC is prevention, both primary prevention, i.e. avoiding exposure to human papillomavirus (HPV) infection and prophylactic vaccination, and secondary prevention, which involves cytologic screening and HPV tests, or both methods together $[6,7]$.

The aim of this study was to assess the knowledge and awareness of women living in the Wielkopolska region (Gniezno district) of the risk factors for cervical cancer.

\section{Material and methods}

The survey used the diagnostic poll method, based on a previously developed survey questionnaire. The study group consisted of 100 women who consented to participate in the study. The study was carried out between March and April 2013. The survey was anonymous and consisted of 21 questions related to age, education, place of residence, housing, obstetric and gynecological history, health behavior, risk factors, and awareness of cervical cancer prevention. All the questions were single-choice questions. In order to diversify the group, the survey was conducted among students of the secondary school in Gniezno (Group I), workers (doctors, nurses and midwives) of two outpatient clinics in the Gniezno district (Group II) and patients of the same clinics (Group III).

\section{Results}

Of all the study subjects, the largest group consisted of women aged 36-50 years. Among the respondents, $48 \%$ had completed secondary education. Most of the respondents indicated a rural place of residence, and $78 \%$ described their living conditions as good. Important elements of the survey involved questions about the health behavior of the respondents. The largest proportion of women who smoked belonged to Group III,

Corresponding author: Karolina Chmaj-Wierzchowska, Department of Maternal and Child Health, University of Medical Sciences, 33 Polna St.

60-535 Poznan, Poland, e-mail: karolinachmaj@poczta.onet.pl

To cite this article: Gawdzik D, Chmaj-Wierzchowska K, Jurczyk MU, Sporny S, Opala T. Knowledge assessment of women living in the Wielkopolska region concerning risk factors for cervical cancer. Prz Menopauzalny 2015; 14: 7-12.

Submitted: 2.09.2014; Accepted: 2.12.2014. 
Tab. I. General characteristics of the study groups

\begin{tabular}{|c|c|c|c|c|}
\hline \multicolumn{2}{|l|}{ Factors } & Group I (\%) & Group II (\%) & Group III (\%) \\
\hline \multicolumn{2}{|c|}{ Age $<20$ yrs } & 93.7 & 0 & 0 \\
\hline \multicolumn{2}{|c|}{ Age $21-35$ yrs } & 6.3 & 6.0 & 43.6 \\
\hline \multicolumn{2}{|c|}{ Age $36-50$ yrs } & 0 & 76.8 & 30.9 \\
\hline \multicolumn{2}{|c|}{ Age $>51$ yrs } & 0 & 17.2 & 25.5 \\
\hline \multicolumn{2}{|c|}{ Primary education } & 100 & 0 & 2.0 \\
\hline \multicolumn{2}{|c|}{ Vocational education } & 0 & 0 & 29.0 \\
\hline \multicolumn{2}{|c|}{ Secondary education } & 0 & 41.4 & 65.4 \\
\hline \multicolumn{2}{|c|}{ Higher education } & 0 & 58.6 & 3.6 \\
\hline \multicolumn{2}{|c|}{ Town up to 50 thousand residents } & 56.3 & 34.0 & 20.0 \\
\hline \multicolumn{2}{|c|}{ City $>50$ thousand residents } & 0 & 13.0 & 9.1 \\
\hline \multicolumn{2}{|l|}{ Village } & 43.7 & 53.0 & 70.9 \\
\hline \multirow[t]{3}{*}{ Housing } & Very good & 18.7 & 37.9 & 7.3 \\
\hline & Good & 75.0 & 62.1 & 87.3 \\
\hline & Satisfactory & 6.3 & 0 & 5.4 \\
\hline
\end{tabular}

whereas the lowest proportion of smokers belonged to Group I. The vast majority did not use oral contraception, and $4 \%$ claimed to have had four or more children. This answer prevailed in Group III. Comparable groups, in terms of size, included women having two (31\%) or three $(27 \%)$ children. Among the respondents, $1 \%$ had

Tab. II. Assessment of health behavior

\begin{tabular}{|c|c|c|c|c|}
\hline Factors & & $\begin{array}{c}\text { Group I } \\
(\%)\end{array}$ & $\begin{array}{c}\text { Group II } \\
(\%)\end{array}$ & $\begin{array}{c}\text { Group III } \\
(\%)\end{array}$ \\
\hline \multirow[t]{2}{*}{ Smoking } & Yes & 18.7 & 37.9 & 49.1 \\
\hline & No & 81.3 & 62.1 & 50.9 \\
\hline \multirow{2}{*}{$\begin{array}{l}\text { Contra- } \\
\text { ception }\end{array}$} & Yes & 31.3 & 10.4 & 23.6 \\
\hline & No & 68.7 & 89.6 & 76.4 \\
\hline \multirow{2}{*}{$\begin{array}{l}\text { Hormone } \\
\text { therapy }\end{array}$} & Yes & 0 & 6.9 & 3.6 \\
\hline & No & 100 & 93.1 & 96.4 \\
\hline \multirow{5}{*}{$\begin{array}{l}\text { Age at } \\
\text { sexual } \\
\text { initiation }\end{array}$} & $<15$ & 6.3 & 0 & 1.8 \\
\hline & 15-16 & 18.7 & 3.5 & 5.4 \\
\hline & 17-18 & 31.2 & 41.4 & 14.5 \\
\hline & $>18$ & 6.3 & 55.1 & 74.5 \\
\hline & $\begin{array}{l}\text { Not } \\
\text { known }\end{array}$ & 37.5 & 0 & 3.8 \\
\hline \multirow{4}{*}{$\begin{array}{l}\text { Number } \\
\text { of sexual } \\
\text { partners }\end{array}$} & 0 & 37.5 & 0 & 3.6 \\
\hline & 1 & 50.0 & 24.1 & 23.6 \\
\hline & 2 & 12.5 & 44.8 & 34.5 \\
\hline & $>3$ & 0 & 31.1 & 38.3 \\
\hline
\end{tabular}

sexual initiation under the age of 15 and $59 \%$ over the age of 18 . The general characteristics of the study population are presented in Tables I and II. Taking into account the relationship between the age of sexual initiation and place of residence, a significant difference can be observed. Sexual initiation under the age of 18 years was more common among women living in urban environments, while over the age of 18 years was more common among residents of rural areas (Fig. 1).

According to the respondents, the main cause of CC is human papillomavirus (Group II - 36\%) and genetic predisposition (Group III-35\%). It is alarming that $26 \%$ of the women did not know what favors the development of CC, especially those in Group I (Fig. 2). One factor that may contribute to the occurrence of CC is smok-

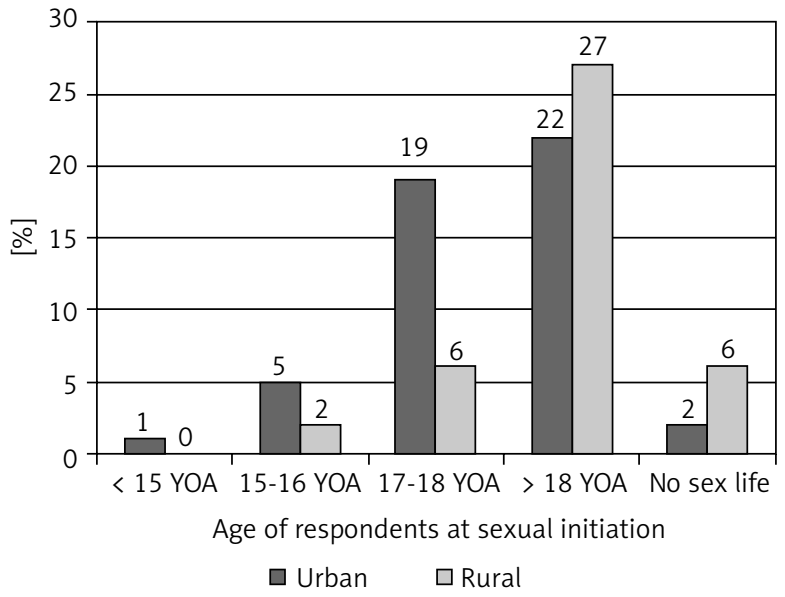

Fig. 1. Age at sexual initiation with respect to the place of residence 


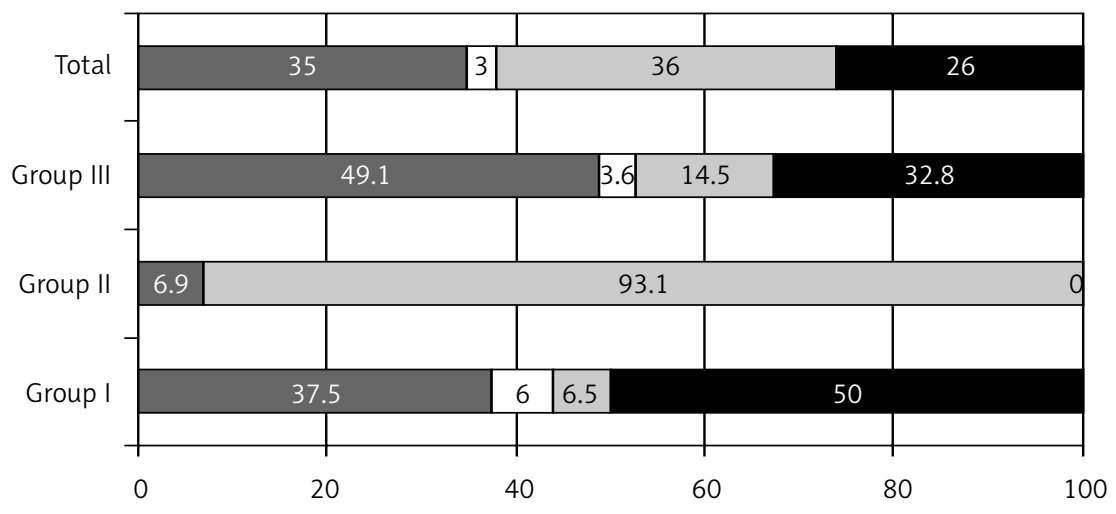

[\%]

$\square$ Genetic predisposition $\quad \square$ Lack of hygiene $\quad \square$ HPV virus $\quad$ I d do not know

Fig. 2. Risk factors for cervical cancer in the study groups

ing (according to $45 \%$ of all respondents) and a large number of births (61\%). The use of contraceptive pills was not included in the risk factors by $63 \%$ of the respondents. Regarding the number of partners and early sexual initiation as risk factors for CC, opinions were divided. According to the vast majority of respondents (85\%), frequent vaginal inflammation and HPV infection are risk factors for CC. Among all the respondents, up to $74 \%$ have heard of a commercially available preventive vaccine, but only $69 \%$ know for whom it is intended. The assessment of the knowledge of risk factors for the development of CC is shown in Table III.

\section{Discussion}

Both primary and secondary prevention is extremely important in preventing the development of CC, and the anonymous survey enabled the accurate checking of the actual level of knowledge of the risk factors for cervical cancer.

\section{Human papillomavirus}

The etiology of CC is inextricably linked with persistent infection caused by highly oncogenic types of HPV [5, 8-11]. In addition to HPV 16 and 18, other types of HPV are also important in carcinogenesis [1, 3, 12, 13]. According to $\mathrm{WHO}$, infection during a 5-year follow-up period affects $10-20 \%$ of people aged $15-49$ years worldwide, of whom $40 \%$ are women under 25 years of age [ 1 , $12,14]$. It is now believed that over $80 \%$ of sexually active women and men are in contact with HPV. However, most of these infections are transient, asymptomatic and they do not cause advanced premalignant changes and CC $[1,12,13,15]$. It is estimated that about $60 \%$ of CIN1, $40 \%$ of CIN2 and $30 \%$ of CIN3 may spontaneously regress without treatment [8]. The risk of progression of CIN1 to CIN3 is $1 \%$ within 1 year, whereas the risk of progression of CIN2 to CIN3 is $16 \%$ within two years, and $25 \%$ within 5 years [5]. According to the respondents, the main reason for CC is HPV and genetic predisposition. It is alarming that $26 \%$ of all respondents (i.e. $50 \%$ of

Tab. III. Assessment of knowledge about risk factors for cervical cancer

\begin{tabular}{|c|c|c|c|c|c|c|}
\hline \multirow[t]{2}{*}{ Factors } & \multicolumn{2}{|c|}{ Group I (\%) } & \multicolumn{2}{|c|}{ Group II (\%) } & \multicolumn{2}{|c|}{ Group III (\%) } \\
\hline & Yes & No & Yes & No & Yes & No \\
\hline Smoking & 43.8 & 56.3 & 62.1 & 37.9 & 36.4 & 63.6 \\
\hline Use of contraceptive pills & 75.0 & 25.0 & 89.6 & 10.4 & 45.5 & 54.6 \\
\hline Large number of births & 37.5 & 62.5 & 79.3 & 20.7 & 58.2 & 41.8 \\
\hline Large number of sexual partners & 56.3 & 43.8 & 82.8 & 17.3 & 29.1 & 70.9 \\
\hline Early sexual initiation & 31.3 & 68.8 & 89.7 & 10.4 & 32.7 & 67.3 \\
\hline Low socioeconomic status & 18.8 & 81.3 & 65.5 & 34.5 & 32.7 & 67.3 \\
\hline Frequent vaginitis - sexually transmitted disease & 81.3 & 18.8 & 96.6 & 3.5 & 80.0 & 20.0 \\
\hline Human papillomavirus infection & 68.8 & 31.3 & 96.6 & 3.5 & 69.1 & 30.9 \\
\hline Preventive vaccination & 37.5 & 62.5 & 100.0 & 0.0 & 70.9 & 29.1 \\
\hline
\end{tabular}


secondary school girls) cannot indicate the main factor responsible for the development of this disease.

\section{Age}

In most countries, the age of CC patients is similar [1, 13]. Most cases worldwide involve women aged 45-54 years [1, 5, 13]. In Poland, since the mid-1980s the largest decrease in morbidity and mortality has been observed among women aged over 30 years $[1,5]$. Currently, cytologic screening remains an essential and indispensable factor in secondary prevention and early detection of CC. The use of screening tests resulted in increased numbers of diagnosed cases of CC and, consequently, reduced rates of morbidity and mortality [16]. Among the respondents, approximately three quarters of women have heard of a commercially available vaccine against oncogenic HPV types. Most (all of Group II) of these women know that it is intended for girls in the age group 11-12 years. Unfortunately, some respondents also believe that sexually active women, pregnant women and those over 50 years of age should also be vaccinated. The survey conducted among secondary school pupils showed that approx. $60 \%$ of the respondents confirmed knowing of a vaccination to prevent CC development. Some of these pupils, mostly secondary schoolgirls, confirmed their willingness to be vaccinated [17].

\section{Early sexual initiation}

Every sexually active woman is exposed to contact with HPV, and very young women are extremely susceptible to this infection. Many scientists emphasize the link between early sexual initiation and HPV infection $[1,18]$. It is believed that the risk of disease increases if sexual initiation takes place under the age of 16 years $[1,12,13]$. A little more than half of the respondents commenced their sexual life over the age of 18 years. Only $4 \%$ of the respondents did not have sexual experiences. It should be noted that those respondents living in urban areas initiated sexual contacts earlier $(\leq 18$ years). Other publications, however, demonstrate that very few women had sexual contacts under the age of 17 years [19]. Michalska et al. [1] have indicated a twofold risk of CC in women who had early sexual initiation ( $\leq 16$ years) [1]. Cervical cancer is rarely diagnosed in celibate nuns, whereas often in prostitutes. Sexual activity, early sexual initiation and a large number of partners increase the risk of HPV infection [20].

\section{Sexual activity - a large number of partners and births}

Epidemiological studies indicate that the intensity of sexual activity and HPV infection play an important role in the development of CC. This risk increases with the number of partners $[1,13]$. An important factor in the development of HPV infection is a considerable number of sexual partners in the two-year period prior to infection [21]. In view of the possibility of transmission of human papillomavirus infections to successive partners and the chronic infection in men, this risk involves both men and women $[1,13]$. Some authors believe that the risk of CC definitely increases in those women who often change sexual partners and women who maintain sexual contacts with more than 10 partners [13]. This also applies to women having sex with a man who frequently changes sexual partners [21]. Sexual activity is also inextricably linked to the number of pregnancies and births [1, 13]. The risk of developing this cancer is two-fold higher in women who give birth to seven or more children [6]. Comparable, in terms of size, the groups included women having two or three children (Group II and III). In contrast, 21\% of the respondents did not have children. In the survey conducted by Nowicki et al. [16], a significant proportion of the surveyed women had three or fewer children. In contrast, 15.9\% of these respondents had not given birth at all [16]. Among women who have given birth more than 3 times the risk is higher compared to women who have given birth less than three times or not at all $[1,16]$. Some authors believe that the number of births is not related to an increased risk of CC [22].

\section{Smoking}

Smoking promotes HPV infection, and infections with highly oncogenic HPV types are more common among habitual smokers [22]. The presence of carcinogenic compounds derived from tobacco smoke in the mucus of the cervix and cervical epithelium is a direct cause of CC development [16, 23]. In addition, it has been found that the risk of HPV infection is two times higher in women who smoke [1]. The risk of developing cervical intraepithelial neoplasia increases with the number of cigarettes smoked per day, and this also applies to women exposed to passive smoking [23]. Disappointing is the fact that $37.93 \%$ of the women with medical education admitted to smoking cigarettes. Suwała et al. [23] in their study demonstrated that "only" $6.5 \%$ of the surveyed nurses were active smokers [23]. Smoking is strongly associated with the increased risk of CC (2-4 times) $[1,12,21]$. This risk increases with the number of cigarettes smoked [1, 12]. Data from 2002 show that in women who have smoked cigarettes, the risk of CC is approx. 1.8 (95\% Cl: 1.72-1.88), and even a greater risk, as much as 2.13 (95\% Cl: 2.02-2.25), if still a smoker [6]. Nicotine is a mutagen and carcinogen that can lead to gene mutations and chromosomal aberrations in epithelial target cells, replicated subsequently in the cells of changed tumors $[1,5]$. Some authors suggest that 
chemical compounds contained in tobacco can lead to a reduction in resistance, which increases the risk of HPV infection and frequency of dysplasia in the cervical epithelium $[13,21]$. Clinical observations conducted among women who smoke clearly show that they have a significantly higher risk of developing CIN compared to women who do not smoke [1]. It was also shown that being with people who smoke may also contribute to the development of CC [6].

\section{Oral hormonal contraception}

Taking combined oral contraceptive pills for 10 years is associated with a two-fold increased risk of CC, and over 10 years may even result in a fourfold risk [1, $6,12]$. Women who use oral contraceptives may have more sexual partners, and those partners are less likely to use condoms than partners of women who do not use oral contraception [12]. It is believed that using gestagens alone is associated with a relatively small increase in the risk of developing CC. Some authors are of the opinion that continuous exposure to estrogens increases the risk by a factor of 2-4. This relationship has been strongly documented in women who have seven children. No increased risk of CC was confirmed in the group of women using intrauterine contraceptive devices that release progestagens [1]. Analyses of studies conducted by WHO show that the risk of adenocarcinoma and carcinoma adenoplanoepitheliale is higher in women using contraceptives under the age of 20 and for over 8 years, and if the chemical composition is low in estrogens and high in gestagens [16].

\section{Immunosuppression}

The effect of immunosuppression on the incidence of many cancers was observed in the 1970s [1]. Over the last decade, the number of people who have had an organ transplant has doubled, resulting in numerous studies of patients after transplantation who require constant immunosuppression [1]. Studies have demonstrated that women receiving immunosuppression associated with HIV infection or following organ transplantation are at increased risk of HPV infection and development of CC $[1,12]$. This relationship seems to be stronger for patients with a decreased percentage of CD4 T-cells [1, 12].

\section{Race}

Epidemiological studies show that differences in the incidence of CC in various regions of the world are associated with a particular race. Both the incidence rate and mortality rate is almost $60 \%$ higher in black women than in white women. The mortality rate among black women is the highest of all ethnic groups. A higher incidence of CC compared to the entire population is observed in Native Americans and Vietnamese women living in America. Such a high incidence among these women is caused by poor access to medical care, socio-economic constraints and cultural barriers. Studies show that the risk of death in a population of Hispanic women is $26 \%$ lower than in black or white women, while in the African-American group the risk of death is $19 \%$ higher compared to other women [1].

\section{Low socioeconomic status}

Low socioeconomic status is often associated with poor housing conditions, poor personal hygiene and inadequate diet [1]. Numerous reports have described a relationship between nutrition and a growing risk of chronic HPV infection and the development of CIN. Protective action with respect to CIN development has been proven for a diet rich in fruits and vegetables (including vitamin C and E, beta carotene and lycopene), folic acid, retinol, vitamin $C, E$ and $B_{12}$. Retinoids play an important role in the proper functioning of cervical epithelial cells. Their deficiency is related to an increased risk of neoplasia [1].

\section{Sexually transmitted diseases}

Some authors emphasize the specific role of persistent infections of the genitourinary tract caused by Chlamydia trachomatis, HSV2 (herpes simplex type 2) [1, 5, 7, 12], Neisseria gonorrhea, Trichomonas vaginalis and Cytomegalovirus [1]. Special attention should be paid to HIV, HSV2 and Chlamydia trachomatis, since it has been demonstrated that the antagonistic action between viruses of low oncogenicity (HPV types 16 and 18) and infections caused by chlamydia leads to the development of CC. In addition, HSV2 infection is associated with an increased risk of carcinoma planoepitheliale and adenocarcinoma [1]. Radiation therapy is an important modality for the treatment of cervical cancers, alone or in combination with surgery [24]. A successful treatment includes not only an improvement on tumor control, but also a reduction in treatment-related complications [25].

Cervical cancer is a leading health problem worldwide, causing approximately 40000 deaths per year in developed nations and 234000 in developing counties annually [26]. The presented results are not optimistic. These data clearly indicate a low level of awareness concerning the prevention of CC among residents of the Gniezno district, which is undoubtedly related to the following factors: insufficient health and sex education in schools, reluctantly conducted conversations on intimate topics in families, and time limitations of 
physicians, who do not always have time to talk to patients about prophylaxis and healthy lifestyles. This is why in this community, and probably also throughout Poland, it is necessary to develop an effective screening program for CC. However, apart from active and widely available screening tests, the level of health awareness among women, regardless of their age or education, is also of importance. Therefore, raising health awareness seems to be the most important issue. Extensive health education can contribute to a reduction in $\mathrm{CC}$ development.

\section{Conclusions}

It is necessary to improve health education as one of the main factors influencing the development of CC and the course of cytologic tests in order to reduce the rates of morbidity and mortality related to this cancer.

\section{Disclosure}

\section{Authors report no conflict of interest.}

\section{References}

1. Michalska M. Epidemiologia raka szyjki macicy. In: Rak szyjki macicy. Spaczyński M, Kędzia W, Nowak-Markwitz E (eds.). Wydawnictwo Lekarskie PZWL, Warszawa 2009; pp. 1-16.

2. Miśta S. Pierwotna profilaktyka raka szyjki macicy - szczepionki przeciwko zakażeniom wirusem HPV. Nowa Klin 2012; 19: 5076-5081.

3. Chybicka A, Jackowska T, Dobrzańska A, et al. Zalecenia grupy ekspertów dotyczące pierwotnej profilaktyki raka szyjki macicy u dziewcząt i młodych kobiet. Med Prakt Pediatr 2011; 1: 25-34.

4. Kędzia W, Józefiniak A, Pruski D, et al. Genotypowanie wirusów brodawczaka ludzkiego u kobiet z CIN 1. Gin Pol 2010; 81: 664-667.

5. Olejek A. HPV jako czynnik etiologiczny raka szyjki macicy. Gin Pol 2008; 79: 126-132.

6. Dębski R. Profilaktyka raka szyjki macicy. In: Rak szyjki macicy Spaczyński M, Kędzia W, Nowak-Markwitz E (eds.). Wydawnictwo Lekarskie PZWL, Warszawa 2009; pp. 40-56.

7. Kędzia W, Spaczyński M. Epidemiologia zakażeń wirusem brodawczaka ludzkiego. In: Rak szyjki macicy. Spaczyński M, Kędzia W, Nowak-Markwitz E (eds.). Wydawnictwo Lekarskie PZWL, Warszawa 2009; pp. 31-38.

8. Kędzia W, Pruski D, Józefiniak A, et al. Genotypowanie onkogennych wirusów brodawczaka ludzkiego u kobiet z rozpoznaniem HG SIL. Gin Pol 2010; 81: 740-744.
9. Majewski S. Ludzki wirus brodawczaka (HPV) i profilaktyka raka szyjki macicy - co powinien wiedzieć pediatra i lekarz rodzinny. Lekarz 2010; 12: 36-40.

10. Spaczyński M. Diagnostyka, profilaktyka i wczesne wykrywanie raka szyjki macicy - rekomendacje Polskiego Towarzystwa Ginekologicznego. Gin Prakt 2004; 12: 6-8

11. Spaczyński M, Nowak-Markwitz E, Januszek-Michalecka L, KarowiczBilińska A. Women's social conditions and their participation in Cervical Cancer Population Screening Program in Poland. Gin Pol 2009; 80: 833-838.

12. Nowakowski AM, Kotarski J. Risk factors of cervical cancer and possibilities of primary prevention. Przegl Epidemiol 2011; 65: 81-88.

13. Suwała M, Gerstenkorn A, Wesołowska R. Knowledge about tobacco smoking as a cervical cancer risk factor among economically active nurses from Lodz region. Przegl Lek 2012; 69: 965-968.

14. Bidziński M, Poręba R. Problem profilaktyki HPV w Polsce. In: Profilaktyka HPV w Polsce. Fundacja MSD dla zdrowia kobiet 2010; pp. 4-11.

15. Spaczyński M, Nowak-Markwitz E, Kędzia W. Skrining raka szyjki macicy w kraju i na świecie. Gin Pol 2007; 78: 354-360.

16. Nowicki A, Borowa I, Maruszak M. Zachowania zdrowotne kobiet w zakresie zapobiegania, wczesnego wykrywania stanów przedrakowych i raka szyjki macicy. Gin Pol 2008; 79: 840-849.

17. Shields T, Brinton L, Burk R, et al. A case-control study of risk factors for invasive cervical cancer among U.S. women exposed to oncogenic types of human papillomavirus. Cancer Epidemiol Biomarkers Prev 2004; 13 : 1574-1582.

18. Grześ B, Heimrath J, Sozański L, Hercuś K. The effectiveness of the quadrivalent HPV vaccine-Silgard in prevention and treatment of condylomata acuminata of the woman's outer sexual organs area. Onkol Pol 2007; 10: 141-144.

19. Knihinicka-Mercik Z, Kazimierczak I, Mess I, et al. Styl życia kobiet przed rozpoznaniem raka szyjki macicy. Onkol Pol 2006; 9: 141-144.

20. Sikorski M. Komentarz do artykułu pt. Od zakażenia ludzkim wirusem brodawczaka ludzkiego do raka szyjki. Med Prakt Onkol 2011; 5: 89-90.

21. Bulsa M, Czaja-Bulsa G. Profilaktyka pierwotna i wtórna raka szyjki macicy. Fam Med Prim Care Rev 2006; 8: 373-374.

22. Nawarra-Karowicz D, Kowalska-Koprek U, Karowicz-Bilińska A. Ocena wystąpienia czynników ryzyka zakażenia wirusem brodawczaka ludzkiego (HPV) oraz stopnia jego onkogenności wśród mieszkanek wsi. Prz Menopauzalny 2005; 4: 22-31.

23. Śmiertka E. Hormonalna terapia zastępcza a niektóre nowotwory narządu rodnego. Gin Pol 2006; 11: 927-932.

24. Beskow C, Ågren-Cronqvist AK, Lewensohn R, Toma-Dasu I. Biological effective dose evaluation and assessment of rectal and bladder com plications for cervical cancer treated with radiotherapy and surgery. J Contemp Brachytherapy 2012; 4: 205-212.

25. Patra NB, Manir KS, Basu S, et al. Effect of bladder distension on dosimetry of organs at risk in computer tomography based planning of highdose-rate intracavitary brachytherapy for cervical cancer. J Contemp Brachytherapy 2013; 5: 3-9.

26. Anderson J, Huang Y, Kim Y. Dosimetric impact of point A definition on high-dose-rate brachytherapy for cervical cancer: evaluations on conventional point $\mathrm{A}$ and MRI-guided, conformal plans. J Contemp Brachytherapy 2012; 4: 241-246. 